\title{
EAl Endorsed Transactions

\section{Do information and communication technologies influence skills, competencies, health and well-being of teenagers? Current evidence}

\author{
Willone Lim ${ }^{1, *}$, Bee Theng Lau ${ }^{1}$, Caslon Chua $^{2}$ and Fakir M Amirul Islam ${ }^{3}$ \\ ${ }^{1}$ Faculty of Engineering, Computing and Science, Swinburne University of Technology, Jalan Simpang Tiga, \\ Kuching, 93350, Sarawak, Malaysia \\ ${ }^{2}$ Faculty of Science, Engineering and Technology, Swinburne University of Technology, Hawthorn, 3122, Victoria, \\ Australia \\ ${ }^{3}$ Faculty of Health, Arts and Design, Swinburne University of Technology, Hawthorn, 3122, Victoria, Australia
}

\begin{abstract}
INTRODUCTION: Information and Communication Technologies are deemed to be a significant influence on teenagers' development. It is important for studies to be conducted to assess the underlying influence of ICT on the teenager age group.

OBJECTIVES: The aim of this paper is to review whether ICT influences teenagers' skills, competencies, health and wellbeing based on previous studies.

METHODS: Articles from 2015 to 2020 were selected for analysis to identify the influences on teenagers.

RESULTS: Computer and mobile devices offer opportunities to improve literacy in digital skills and competencies. It is also evident that teenagers are prone to risks of getting musculoskeletal symptoms as a result of excessive use of such devices, and it also leads to unforeseen illnesses such as depression in the case of teenager's well-being.

CONCLUSION: Adopting ICT may have beneficial implications for teenagers, but it can pose more adverse effects on their development when used excessively.
\end{abstract}

Keywords: Information and communication technology, skills, competencies, health, well-being, influence, teenager.

Received on 14 January 2021, accepted on 30 March 2021, published on 06 April 2021

Copyright (C) 2021 Willone Lim et al., licensed to EAI. This is an open access article distributed under the terms of the Creative Commons Attribution license, which permits unlimited use, distribution and reproduction in any medium so long as the original work is properly cited.

doi: 10.4108/eai.6-4-2021.169174

"Corresponding author. Email: wilim@swinburne.edu.my

\section{Introduction}

The proliferation of ICT has become an essential medium for the young generation to learn about new tools in this interconnected world. The Digital revolution is prevalent and its influence is remarkable, which can be seen in how millennials or digital natives are already used to living with technologies. ICT offers teenagers learning opportunities and digital citizenship, as well as preparing themselves for future employment [1]. ICT tools are used extensively among teenagers to enhance their overall learning experience. For instance, the internet and mobile phone are important to help teenagers in learning processes; these tools are essential for preparing for work as well as looking for school-related information [2]. The Internet has profoundly reshaped education as it offers more opportunities for students to improve their knowledge [3]. Learning activities supported by online learning tools provide the most effective learning domain in higher education [4], particularly during the current state of the COVID-19 pandemic, where all learning has been shifted to online. Online learning equips students with knowledge and 
experience of the learning process that balances the development of times and technology used based on the ability of self-regulation [5]. Similarly, students who utilize online learning methods can improve their technical skills, which include performing in-depth research online, the ability to use new software and communicate effectively during online classes [6].

The adoption of mobile learning has enhanced students' digital skills, for example, searching for information to complete assignments and preparing written reports efficiently [7]. Moreover, Hamidi and Chavoshi [8] confirmed that mobile learning improves students' ability to communicate and access information through mobile devices. Around $77.2 \%$ of students stated that mobile devices provide flexibility for learning and 55.6\% agreed that mobile learning increases their motivation to learn [9]. Despite the encouraging benefits, studies have shown the adverse effects of mobile phone usage among students. A study reported that teenagers turned their skills into illegal practices, such as using mobile phones for cheating by downloading online sources and plagiarize others' work without acknowledgement [10]. Besides, in a study conducted in a local university in Malaysia, the authors expressed their concern with the fact that students are using their digital skills to conduct unethical activities, which are hacking $(15 \%)$, movie piracy $(67 \%)$ and gambling $(7 \%)$ [11].

Social networking is prevalent among teenagers as a way to make connections, socializing, as well as for knowledge sharing and learning [12]. The emergence and intensive use of social networking sites has seen the growth of popular social networking sites (SNS) like Facebook, Instagram, and Twitter. According to the study, the majority of students from university use social networking sites as a common tool for chatting and discussions such that WhatsApp (92.5\%), YouTube (82.8\%) and Facebook (74.4\%) [12]. Most students are using social networking sites for information sharing, discussions and collaboration to complete assignments. Similarly, an online survey conducted at a public university found that $65 \%$ of students use social networking sites for information gathering and $55 \%$ of students use them for sharing information and materials [13]. In fact, students in higher education acknowledge the advantages of social networking sites for educational purposes, including communicating with peers and instructors in addition to strengthening their critical thinking and self-management learning [14].

Additionally, teenagers spent most of their time engaging with ICTs on leisure and entertainment such as browsing the internet, listening to music and playing online games. However, many researchers have debated the disadvantages of online gaming, but teenagers can definitely benefit from it if used in a controlled manner. Tsappis [15] asserted that online gaming offers relief to teenagers who struggle with the transition to college by providing entertainment and enjoyment, a platform to demonstrate their gaming skills, resulted in a sense of competence and provide an opportunity for social connectedness. Besides, learning incorporated with game mechanics as an online puzzle- based game has improved students' algorithmic thinking skills [16]. Dumrique and Castillo [17] found that playing online games does not affect the students' academic performance and the majority of students $(73.5 \%)$ that do not engage in before-school play are unlikely to exhibit poor academic performance [18].

The ever-increasing growth of ICTs has proved to have benefits and positive influences along the path. Despite the encouraging signs on ICT use, there is still ongoing concern about whether the usage is detrimental as well, particularly related to well-being and health. The excessive use of electronic media in daily activities was associated with experienced discomfort in sore eyes, neck pain or musculoskeletal pain [19]. For instance, researchers reported that $74 \%$ of the students who used smartphones/tablets are experiencing neck or shoulder pain, while $80 \%$ have one or more visual symptoms [20]. Furthermore, social media has become an integral part of teenagers' lives and habitual usage will pose more harm than good. As a result, studies concluded that the risk of using social media is connected to the exposure to a harmful substance [21] and teenagers who are categorized as creative user - very high usage of social sites; $70 \%-80 \%$ higher odds of using combustible tobacco [22].

This article aims to identify and analyse the current evidence on how different types of information and communication technologies will influence teenagers' development in terms of skills, competencies, health and well-being. Although there are reviews of both positive and negative influences of ICT usage on teenagers [23,24], they do not address the influence based on the four major components as a whole and they do not fit the aim of this review paper. In their review, Siddiq et al. [23] focuses on digital literacy and computer-based assessment, of which majority are targeting lower secondary students (aged 11 to 14 years old). In contrast, Wu et al. [24] touches on the circumstances of internet technology use on health and wellbeing, however, the study is focusing mainly on the positive side. Neither of these reviews has discussed on the effects of different ICTs on the four aspects. Therefore, this survey was conducted to increase knowledge, understanding and validate theories in which technologies can enhance or deprive teenagers' development. It is also meant to increase awareness of the public, especially among teenagers, on the benefits or drawbacks of adopting ICTs in their lives.

Due to the limited number of papers on influences of ICT on teenagers, study on adolescent and youth were also included for consideration in this review.

\section{Influence of ICT on Teenager}

\subsection{Skills}

In the modern world, ICT benefits are abundant and apparent, especially in offering opportunities to teenagers in skills development. Teenagers are active consumers of the 
internet and gadgets that explore information either for leisure or academic purposes. The constant use of technologies had refined their digital knowledge to have a greater perception of online risk [25]. A similar finding from a study conducted in South Korea, where students who are often engaged on the internet, have a higher device and content literacy [26].

Besides, digitally skilled teenagers retain more benefits from digital technologies by using their skills effectively and can cope with online risk [27]. Furthermore, Viloria et al. [28] have investigated mobile devices among Spanish and Hispanic-Americans, showing that $9.35 \%$ of students are using digital skills for academic information search, studies and consultation. Also, the presence of ICTs in education institutions is the key factor for teenagers to improve their digital literacy and subsequently prepare themselves for job employability [29]. For instance, digitally literate teenagers have the ability to use or communicate through digital technologies effectively and practicing safe search without taking risks on the internet [30]. Additionally, digital technologies enrich students' digital skills and literacy to support their learning where, the study reported that the majority of the students (37.65\%) perceived their digital literacy on the scale of "very good", that engage in online learning [31].
Moreover, Gioiosa and Kinkela [32] had a similar result in their survey conducted on college students in New York, in which $78 \%$ of students agreed on the blending of technologies in classes has improved their communication skills and facilitate information search on the internet. On the other hand, several studies deny the benefits of the internet on teenagers' skills where abusive usage was identified. Teenagers can facilitate technologies and explore the benefits of social interaction in their daily lives; however, uncontrolled use has risen to the extent of misusing to harm others. For example, a study was carried out in England shows that $1.9 \%$ of students are the perpetrator of cyberbullying in misusing their ICT skills to harm others [33].

Moreover, a study by Ugur and Koc (2015) reported nearly $80 \%$ of students are misusing their digital skills in the classroom by using mobile devices for phubbing and cheating, which are tallied with the findings from [35] that the prevalence of cheating happening in classrooms and it is indicated that male students are more likely to plagiarize compared to female students. However, the disparity in terms of ICT exposure between urban and rural areas is a point of concern as Asfar and Zainuddin [36] responded that students (15\%) from rural areas in Selangor, Malaysia has lower ICT skills and self-directed learning readiness compared to students $(85 \%)$ from urban areas.

Table 1. Studies on the influence of ICT on skills.

\begin{tabular}{|c|c|c|c|c|}
\hline Publication & Scope & Region & Positive influence & Negative influence \\
\hline $\begin{array}{l}\text { Asfar \& } \\
\text { Zainuddin, } 2015\end{array}$ & $\begin{array}{l}\text { ICT in self-directed } \\
\text { learning }\end{array}$ & $\begin{array}{l}\text { Asia (urban and } \\
\text { rural areas in } \\
\text { Selangor, } \\
\text { Malaysia) }\end{array}$ & & $\begin{array}{l}15 \% \text { from rural areas has } \\
\text { less ICT skills compared } \\
\text { to } 85 \% \text { from urban areas }\end{array}$ \\
\hline $\begin{array}{l}\text { Cabello-Hut et } \\
\text { al., } 2017\end{array}$ & $\begin{array}{l}\text { Digital skills and online } \\
\text { opportunities }\end{array}$ & America (Brazil) & $\begin{array}{l}\text { Ability to use, communicate } \\
\text { and avoiding taking risk from } \\
\text { the internet }\end{array}$ & \\
\hline $\begin{array}{l}\text { Gioiosa \& } \\
\text { Kinkela, } 2019\end{array}$ & $\begin{array}{l}\text { Technology and } \\
\text { communication skills }\end{array}$ & $\begin{array}{l}\text { America (New } \\
\text { York, United } \\
\text { States) }\end{array}$ & $\begin{array}{l}\text { Using technology further } \\
\text { improve the learning process }\end{array}$ & \\
\hline $\begin{array}{l}\text { Lareki et al., } \\
2017\end{array}$ & $\begin{array}{l}\text { Perception on the } \\
\text { impact of technology }\end{array}$ & $\begin{array}{l}\text { Europe (Basque } \\
\text { Country and } \\
\text { Navarre, Spain) }\end{array}$ & $\begin{array}{l}\text { Participants who use } \\
\text { technologies are aware of the } \\
\text { online risk }\end{array}$ & \\
\hline $\begin{array}{l}\text { McGuinness \& } \\
\text { Fulton, } 2019\end{array}$ & $\begin{array}{l}\text { Digital skills on e- } \\
\text { learning }\end{array}$ & $\begin{array}{l}\text { Europe (Dublin, } \\
\text { Republic of } \\
\text { Ireland) }\end{array}$ & $\begin{array}{l}\text { Digital technology enriches } \\
\text { online learning opportunities }\end{array}$ & \\
\hline $\begin{array}{l}\text { Negre et al., } \\
2015\end{array}$ & Academic cheating & Europe (Spain) & & $\begin{array}{l}\text { Male students are more } \\
\text { likely to conduct cheating } \\
\text { in the classroom }\end{array}$ \\
\hline Park et al., 2015 & Digital media literacy & $\begin{array}{l}\text { Asia (South } \\
\text { Korea) }\end{array}$ & $\begin{array}{l}\text { Participants who engaged in } \\
\text { online activities have higher } \\
\text { digital literacy }\end{array}$ & \\
\hline $\begin{array}{l}\text { Picatoste et al., } \\
2018\end{array}$ & $\begin{array}{l}\text { Impact of ICT on } \\
\text { teenager's development }\end{array}$ & Europe (Spain) & $\begin{array}{l}\text { ICT is a key factor for } \\
\text { teenagers to improve digital } \\
\text { literacy }\end{array}$ & \\
\hline $\begin{array}{l}\text { Rodríguez-de- } \\
\text { Dios et al., } 2018\end{array}$ & $\begin{array}{l}\text { Impact of digital skills } \\
\text { on online opportunities } \\
\text { and risk }\end{array}$ & $\begin{array}{l}\text { Europe (urban } \\
\text { and rural areas, } \\
\text { Spain) }\end{array}$ & $\begin{array}{l}\text { Digital literacy provides more } \\
\text { benefits from digital } \\
\text { technologies and may avoid } \\
\text { risk or harm }\end{array}$ & \\
\hline $\begin{array}{l}\text { Ugur \& Koc, } \\
2015\end{array}$ & Mobile phones usage & $\begin{array}{l}\text { Asia } \\
\text { (Sakarya, Turkey) }\end{array}$ & & $\begin{array}{l}80 \% \text { of students are } \\
\text { distracted, phubbing. }\end{array}$ \\
\hline
\end{tabular}




\begin{tabular}{|l|l|l|l|l|}
\hline Publication & Scope & Region & Positive influence & Negative influence \\
\hline & & & $\begin{array}{l}\text { and cheating during an } \\
\text { exam. }\end{array}$ \\
\hline $\begin{array}{l}\text { Viloria et al., } \\
2020\end{array}$ & $\begin{array}{l}\text { The use of mobile } \\
\text { devices to carry out } \\
\text { academic activities }\end{array}$ & $\begin{array}{l}\text { America (Latin } \\
\text { America) }\end{array}$ & $\begin{array}{l}\text { Mobile devices are used for } \\
\text { academic information search, } \\
\text { studies and consultation }\end{array}$ & \\
\hline West, 2015 & $\begin{array}{l}\text { Prevalence of } \\
\text { cyberbullying }\end{array}$ & $\begin{array}{l}\text { Europe (England, } \\
\text { UK) }\end{array}$ & & $\begin{array}{l}7.9 \% \text { of students are } \\
\text { victims of cyberbullying }\end{array}$ \\
\hline
\end{tabular}

\subsection{Competencies}

Teenagers that use the internet are mostly technology savvy and this indicates that teenagers who understand the background of the internet and information findings can perform better in academic competence [37]. The following study carried out in Universities in the South-West of Nigeria has a similar outcome where a significant of $88.2 \%$ of female and $83.3 \%$ of male students agreed that having learning materials on mobile devices improves overall learning [38]. The authors confirmed that mobile devices' familiarity among students enhances their learning by instantly updating resources that are easily accessible through the internet [39].

Students use mobile phones to learn new things and indirectly increase their searching and learning skills, but overuse causes them to be unable to concentrate on studies and leads to poor performance in exams [40]. The study has a similar result that students with higher phone time usage have a lower GPA than the students who use it less, where the descriptive analysis concluded that females have higher
GPA $($ Mean $=3.09)$ compared to males $($ Mean $=2.88)$ [41] and Domoff et al. [42] believed that the decrease in academic performance causes by smartphone addiction especially during class lessons.

However, a survey was carried out among high school students in Malaysia to identify the association of gadgets uses and their academic performance has a differing result that both males and females shared the same academic competencies in which $57.5 \%$ of them has poor performance and spent more than 6 hours on gadgets [43]. Whereas, in terms of digital divide, students from rural areas have fewer competencies as they have limited access to ICT facilities [44]. Despite the bounded access to ICT, Thinakaran et al. [45] revealed that students from rural areas in Malaysia have a high computer self-efficacy for basic and advanced skills. In contrast, a study conducted on other rural areas in Malaysia showed a gender divide where males have higher digital skills than females [46].

Table 2. Studies on the influence of ICT on competencies.

\begin{tabular}{|l|l|l|l|l|}
\hline Publication & Scope & Region & Positive influence & Negative influence \\
\hline Ahmad et al., 2019 & Digital skills level & $\begin{array}{l}\text { Asia (urban and rural } \\
\text { areas in Hulu Langat, } \\
\text { Selangor, Malaysia) }\end{array}$ & $\begin{array}{l}\text { Males have higher } \\
\text { digital skills compared } \\
\text { to females }\end{array}$ \\
\hline $\begin{array}{l}\text { Buabeng-Andoh \& } \\
\text { Issifu, 2015 }\end{array}$ & $\begin{array}{l}\text { ICT literacy of } \\
\text { secondary school } \\
\text { students }\end{array}$ & $\begin{array}{l}\text { Africa (urban and rural } \\
\text { areas in Ghana) }\end{array}$ & $\begin{array}{l}\text { Lack of ICT facilities } \\
\text { for learning }\end{array}$ \\
\hline Domoff et al., 2020 & Addictive phone use. & $\begin{array}{l}\text { America (Northern } \\
\text { Midwest, United } \\
\text { States) }\end{array}$ & & $\begin{array}{l}\text { Addictive phone use } \\
\text { caused a decrease in } \\
\text { academic performance }\end{array}$ \\
\hline Lepp et al., 2015 & $\begin{array}{l}\text { Effect of cell phone } \\
\text { use on grade point } \\
\text { average }\end{array}$ & $\begin{array}{l}\text { America } \\
\text { (United States) }\end{array}$ & $\begin{array}{l}\text { High cell phone use } \\
\text { had a significantly } \\
\text { lower GPA }\end{array}$ \\
\hline Othman et al., 2020 & $\begin{array}{l}\text { Impact of electronic } \\
\text { gadgets on academic } \\
\text { performance }\end{array}$ & $\begin{array}{l}\text { Asia (Kuantan, } \\
\text { Pahang, Malaysia) }\end{array}$ & $\begin{array}{l}\text { Students spent the } \\
\text { most time on } \\
\text { electronic gadget has } \\
\text { a poor academic } \\
\text { achievement }\end{array}$ \\
\hline Pagani et al., 2016 & $\begin{array}{l}\text { Effects of digital } \\
\text { literacy on educational } \\
\text { outcomes }\end{array}$ & Europe (Italy) & $\begin{array}{l}\text { Digital skills have a } \\
\text { positive relationship } \\
\text { with higher academic } \\
\text { performance for both } \\
\text { math and reading }\end{array}$ & Learning materials on \\
\hline Shonola et al., 2016 & Impact of mobile & Africa (Nigeria) & \\
\hline
\end{tabular}




\begin{tabular}{|l|l|l|l|l|}
\hline Publication & Scope & Region & Positive influence & Negative influence \\
\hline device on learning & & $\begin{array}{l}\text { mobile devices } \\
\text { improve overall } \\
\text { learning }\end{array}$ & \\
\hline Thinakaran et al., 2018 & $\begin{array}{l}\text { Perceived computer } \\
\text { self-efficacy }\end{array}$ & $\begin{array}{l}\text { Asia (rural areas in } \\
\text { Malaysia) }\end{array}$ & $\begin{array}{l}\text { Basic and advanced } \\
\text { skills have a higher } \\
\text { self-efficacy level }\end{array}$ & \\
\hline $\begin{array}{l}\text { Venkatapathy \& } \\
\text { Bhargavan, 2020 }\end{array}$ & $\begin{array}{l}\text { Usage of smartphone } \\
\text { and academic } \\
\text { performance }\end{array}$ & $\begin{array}{l}\text { Asia (Puducherry, } \\
\text { India) }\end{array}$ & $\begin{array}{l}\text { Overuse of } \\
\text { smartphones causing } \\
\text { students unable to } \\
\text { concentrate on their } \\
\text { studies }\end{array}$ \\
\hline
\end{tabular}

\subsection{Health}

The advancement of ICT in the health sector is distinguishable between developed and underdeveloped countries; however, teenagers from rural areas have poor access to technologies in improving their health where the existing barriers like socioeconomic status and geographical location restrict their approach to ICT [47]. Therefore, the author introduced mHealth as one of the possible solutions to overcome these barriers; the study was carried out in Dhaka shows that perceived ease of use was a significant factor in the students' intention to use mHealth [48]. For example, CopeSmart, a telemental health application through self-monitoring, has the potential to encourage positive teenagers' mental health. $79 \%$ of the participants regarded the app as a medium to monitor their health and increase awareness of their emotions [49]. Harrer et al. [68] support the internet-based mobile health application is effective to reduce the consequences of college-related stress and might provide help for students who are suffering from depression.

However, a report from high school students in the United States shows that students who spent time on TV or other screen devices for more than 5 hours a day are linked to obesity (78\%), less physical activity (94\%), and inadequate sleep (80\%) [51] which is higher compared to the result reported from college students in China who are suffering from poor sleep quality (9.8\%) [52] and (29.4\%) from Pittsburgh, United States [53]. Simultaneously, a sedentary lifestyle among teenagers was more often contributes to the increase in weight and obesity [54] that may cause health complications [55]. According to the study, teenagers who spent more than 2 hours $(36.8 \%)$ on digital devices in a single sitting were subjected to overweight (14.4\%) and obese (11.9\%) [56].

Besides, the study found that the increase in musculoskeletal and visual symptoms is related to the increase in phone and tablet usage [57]. The consequences can be seen from the result gathered, where $8.3 \%(n=112)$ of the participants are categorized as obese and almost half of the participants $48.3 \% \quad(n=653)$, reported experiencing musculoskeletal pain [58]. Also, Woo et al. [77] asserted that physical pain appears when the body and mind's movement is restrained, where their study revealed that $49.9 \%$ of students are having upper limb musculoskeletal discomfort.

Table 3. Studies on the influence of ICT on health.

\begin{tabular}{|l|l|l|l|l|}
\hline Publication & Scope & Region & Positive influence & Negative influence \\
\hline $\begin{array}{l}\text { Bradbury et } \\
\text { al., 2019 }\end{array}$ & $\begin{array}{l}\text { Sweet beverage } \\
\text { intake and the use of } \\
\text { electronic devices }\end{array}$ & $\begin{array}{l}\text { America (United } \\
\text { States) }\end{array}$ & $\begin{array}{l}\text { A sedentary lifestyle } \\
\text { contributed to the } \\
\text { consumption of sugary } \\
\text { beverages that may cause } \\
\text { health complications }\end{array}$ \\
\hline $\begin{array}{l}\text { Cai et al., } \\
2017\end{array}$ & $\begin{array}{l}\text { Screen-time viewing } \\
\text { and overweight }\end{array}$ & $\begin{array}{l}\text { Asia (Beijing, } \\
\text { Shanghai, Tianjin, } \\
\text { Chongqing, Mongolia, } \\
\text { Xinjiang, Guangxi, } \\
\text { Ningxia, Tibet, China) }\end{array}$ & & $\begin{array}{l}11.9 \% \text { were overweight, } \\
\text { teenagers exceeded daily } \\
\text { screen-time of 2 hours }\end{array}$ \\
\hline $\begin{array}{l}\text { Goicolea et } \\
\text { al., 2018 }\end{array}$ & Health care access & Europe (Sweden) & & $\begin{array}{l}\text { Young people from rural } \\
\text { areas have limited access to } \\
\text { health technologies }\end{array}$ \\
\hline $\begin{array}{l}\text { Harrer et al., } \\
2018\end{array}$ & $\begin{array}{l}\text { Efficacy of internet- } \\
\text { based and app- } \\
\text { supported stress }\end{array}$ & Europe (Germany) & $\begin{array}{l}\text { Internet-based mobile } \\
\text { health application is } \\
\text { effective to reduce the }\end{array}$ & \\
\hline
\end{tabular}




\begin{tabular}{|c|c|c|c|c|}
\hline Publication & Scope & Region & Positive influence & Negative influence \\
\hline & intervention & & $\begin{array}{l}\text { consequences of college- } \\
\text { related stress and } \\
\text { depression }\end{array}$ & \\
\hline $\begin{array}{l}\text { Harris et al., } \\
2015\end{array}$ & $\begin{array}{l}\text { Computer exposure to } \\
\text { musculoskeletal pain }\end{array}$ & $\begin{array}{l}\text { Oceania (Perth, } \\
\text { Australia) }\end{array}$ & & $\begin{array}{l}8.3 \% \text { of the participants are } \\
\text { categorized as obese and } \\
\text { almost half of the participants } \\
48.3 \% \text { reported experiencing } \\
\text { musculoskeletal pain }\end{array}$ \\
\hline Hoque, 2016 & $\begin{array}{l}\text { mHealth adoption in a } \\
\text { developing country }\end{array}$ & $\begin{array}{l}\text { Asia (Dhaka, } \\
\text { Bangladesh) }\end{array}$ & $\begin{array}{l}\text { Perceived ease of use had } \\
\text { a significant positive } \\
\text { impact on the intention to } \\
\text { adopt mHealth service }\end{array}$ & \\
\hline $\begin{array}{l}\text { Huang et al., } \\
2020\end{array}$ & $\begin{array}{l}\text { Poor sleep quality } \\
\text { from smartphone } \\
\text { usage }\end{array}$ & $\begin{array}{l}\text { Asia (Changsha, } \\
\text { China) }\end{array}$ & & $\begin{array}{l}\text { Mobile phone addiction } \\
\text { contributed to poor sleep } \\
\text { quality and poor physical } \\
\text { health. }\end{array}$ \\
\hline $\begin{array}{l}\text { Kenney \& } \\
\text { Gortmaker, } \\
2017\end{array}$ & $\begin{array}{l}\text { Impact of screen } \\
\text { devices and obesity } \\
\text { risk factors }\end{array}$ & $\begin{array}{l}\text { America (United } \\
\text { States) }\end{array}$ & & $\begin{array}{l}\text { Participants that spent the } \\
\text { most time on devices was } \\
\text { associated with obesity, less } \\
\text { physical activity and sleep } \\
\text { disturbance }\end{array}$ \\
\hline $\begin{array}{l}\text { Kenny et al., } \\
2015\end{array}$ & $\begin{array}{l}\text { CopeSmart, a } \\
\text { telemental health app } \\
\text { promote positive } \\
\text { health outcomes }\end{array}$ & $\begin{array}{l}\text { Europe (Dublin, } \\
\text { Republic of Ireland) }\end{array}$ & $\begin{array}{l}79 \% \text { of the participants } \\
\text { regard the app as a } \\
\text { medium to monitor their } \\
\text { health and increase } \\
\text { awareness of their } \\
\text { emotions }\end{array}$ & \\
\hline $\begin{array}{l}\text { Levenson et } \\
\text { al., } 2016\end{array}$ & $\begin{array}{l}\text { Social media and } \\
\text { sleep deprivation }\end{array}$ & $\begin{array}{l}\text { America (United } \\
\text { States) }\end{array}$ & & $\begin{array}{l}\text { Participants who use social } \\
\text { media and devices had } \\
\text { greater odds of having sleep } \\
\text { disturbance }\end{array}$ \\
\hline $\begin{array}{l}\text { Puolitaival et } \\
\text { al., } 2020\end{array}$ & $\begin{array}{l}\text { The use of digital } \\
\text { devices with poor } \\
\text { eating habits and } \\
\text { physical activity }\end{array}$ & $\begin{array}{l}\text { Europe (Oulu, } \\
\text { Finland) }\end{array}$ & & $\begin{array}{l}\text { Participants who spent time } \\
\text { on video gaming }(3 \mathrm{~h} / \mathrm{d}) \text { had } \\
\text { lower physical fitness, obese, } \\
\text { and poor dietary habits }\end{array}$ \\
\hline $\begin{array}{l}\text { Straker et al., } \\
2018\end{array}$ & $\begin{array}{l}\text { Impact of mobile } \\
\text { technology }\end{array}$ & $\begin{array}{l}\text { Oceania (Perth, } \\
\text { Australia) }\end{array}$ & & $\begin{array}{l}\text { The increase in } \\
\text { musculoskeletal and visual } \\
\text { symptoms is related to the } \\
\text { increased use of phones and } \\
\text { tablets. }\end{array}$ \\
\hline $\begin{array}{l}\text { Woo et al., } \\
2016\end{array}$ & $\begin{array}{l}\text { Musculoskeletal } \\
\text { impacts of the use of } \\
\text { devices }\end{array}$ & Asia (Hong Kong) & & $\begin{array}{l}\text { Participants who use gadgets } \\
\text { has neck and shoulder pain }\end{array}$ \\
\hline
\end{tabular}

\subsection{Well-being}

The question of whether the use of ICT such as mobile devices, the internet and social media can benefit or detriment teenagers' well-being remains unclear. A study concerning teenagers' well-being and social media usage in the Netherlands found that $45.90 \%$ of the participants felt better after using social media like Instagram and WhatsApp [60]. However, Meier et al. [48] denied that social media offer benefits for students and their analysis found that students often procrastinate in completing school tasks while using Facebook, which contributed to academic stress and negative well-being. Also, the extensive use of social media has raised concerns about the issue regarding cyber- aggression resulting in mental health problems among teenagers [62].

Besides, mobile health application usage has reduced somatic anxiety by $18 \%$ and depression symptoms by $22 \%$, to a manageable level, and improves students' quality of life [63]. On the other hand, the authors argue that prolonged mobile phone use for more than 2 hours per day among teenagers has significantly contributed to a higher risk of depression [64]. Meanwhile, social media use also posed a threat to teenagers' well-being as according to the study, 201 out of 225 Instagram post contains Non-suicidal self-injury (NSSI) hashtag which is associated to depression and selfharm [65]. Moreover, M. Liu et al. [53] and Wahyuni et al. 
[54] agreed that exposure to digital technologies for more than two hours per school day shows a high risk of selfharm and psychiatric problems.

Furthermore, Chen et al. [55] asserted that the high frequency of mobile phone use is associated with suicidal and self-harm ideation. McDool et al. [56] voiced their concern on children's negative relationship between internet use and well-being, with their findings on girls having the most potent effect on feeling depressed about their appearance, social life and school work. Woods and Scott [57] responded that social media usage, especially at night, is linked to poor sleep quality and increased anxiety and depression levels.

Also, teenagers with excessive social media use show a higher risk of getting aggressive and conduct problems [71]. Wang et al. [59], in contrast, approximately $95 \%$ of students used screen devices before sleep and between them, girls showed a higher chance of getting anxiety symptoms. The same outcome from the findings $[73,74]$, where girls exhibit a higher level of depression. Interestingly, a study by Tangmunkongvorakul et al. [62] shows that $58.7 \%$ of excessive smartphone users are female students and they are more likely to suffer from psychological well-being. In 2015, the authors investigated the influence of ICT among urban youth in America and found that an increase in ICT usage related significantly to depression and hopelessness [76].

Meanwhile, a different study was conducted in a developing country, South Africa, discovered high computer usage on learning by working students $(57 \%)$ but low prevalence of excessive use symptoms (7\%) and medium loss of sleep (54\%) because of work commitments [77].

Table 4. Studies on the influence of ICT on well-being.

\begin{tabular}{|c|c|c|c|c|}
\hline Publication & Scope & Region & Positive influence & Negative influence \\
\hline Beyens et al., 2020 & $\begin{array}{l}\text { Effect of social media } \\
\text { on well-being }\end{array}$ & $\begin{array}{l}\text { Europe } \\
\text { (Netherlands) }\end{array}$ & $\begin{array}{l}46.90 \% \text { of participants } \\
\text { reported feeling better after } \\
\text { using social media }\end{array}$ & \\
\hline Chen et al., 2020 & $\begin{array}{l}\text { Relationship between } \\
\text { mobile phone use and } \\
\text { suicidal intention }\end{array}$ & $\begin{array}{l}\text { Asia (Shenzhen, } \\
\text { China) }\end{array}$ & & $\begin{array}{l}\text { High frequency of mobile } \\
\text { phone use effect suicidal } \\
\text { and self-harming actions }\end{array}$ \\
\hline Coleman et al., 2015 & $\begin{array}{l}\text { ICT usage on } \\
\text { psychological well- } \\
\text { being }\end{array}$ & $\begin{array}{l}\text { America } \\
\text { (Southeastern } \\
\text { United States) }\end{array}$ & & $\begin{array}{l}\text { Increased usage of ICT } \\
\text { related significantly to } \\
\text { depression and } \\
\text { hopelessness }\end{array}$ \\
\hline Demirci et al., 2015 & $\begin{array}{l}\text { Impact of } \\
\text { smartphones on } \\
\text { health }\end{array}$ & $\begin{array}{l}\text { Asia (Isparta, } \\
\text { Turkey) }\end{array}$ & & $\begin{array}{l}\text { The use of smartphone } \\
\text { regularly exhibits a } \\
\text { higher level of } \\
\text { depression }\end{array}$ \\
\hline George et al., 2020 & $\begin{array}{l}\text { Digital technology on } \\
\text { well-being }\end{array}$ & $\begin{array}{l}\text { America (North } \\
\text { Carolina, United } \\
\text { States) }\end{array}$ & & $\begin{array}{l}\text { High usage on social } \\
\text { media was associated } \\
\text { with conduct problems }\end{array}$ \\
\hline J. Liu et al., 2019 & $\begin{array}{l}\text { Prolonged mobile } \\
\text { phone use }\end{array}$ & $\begin{array}{l}\text { Asia (Shandong, } \\
\text { China) }\end{array}$ & & $\begin{array}{l}\text { Higher phone usage was } \\
\text { connected to the } \\
\text { increased risk of } \\
\text { depression symptoms }\end{array}$ \\
\hline M.Liu et al., 2016 & $\begin{array}{l}\text { Associations of digital } \\
\text { screen with } \\
\text { psychiatric symptoms } \\
\text { and suicidal ideation }\end{array}$ & $\begin{array}{l}\text { Asia (urban } \\
\text { areas in China) }\end{array}$ & & $\begin{array}{l}\text { Exposure to digital } \\
\text { technologies shows a } \\
\text { high risk of self-harm and } \\
\text { psychiatric problem }\end{array}$ \\
\hline McDool et al., 2020 & $\begin{array}{l}\text { Use of internet and } \\
\text { well-being outcomes } \\
\text { in children. }\end{array}$ & $\begin{array}{l}\text { Europe } \\
\text { (England) }\end{array}$ & & $\begin{array}{l}\text { Girls having the } \\
\text { strongest effect on } \\
\text { feeling depressed about } \\
\text { their appearance, social } \\
\text { life and school work }\end{array}$ \\
\hline Meier et al., 2016 & $\begin{array}{l}\text { Procrastination with } \\
\text { social media impacted } \\
\text { academic and well- } \\
\text { being }\end{array}$ & $\begin{array}{l}\text { Europe } \\
\text { (Germany) }\end{array}$ & & $\begin{array}{l}\text { Procrastinating while } \\
\text { using Facebook } \\
\text { contributed to academic } \\
\text { stress and negative well- } \\
\text { being }\end{array}$ \\
\hline Mishna et al., 2018 & $\begin{array}{l}\text { Cyber-aggression and } \\
\text { mental health }\end{array}$ & $\begin{array}{l}\text { North America } \\
\text { (Canada) }\end{array}$ & & $\begin{array}{l}\text { Social media use has } \\
\text { raised issues regarding } \\
\text { cyberbully and mental } \\
\text { health concern }\end{array}$ \\
\hline
\end{tabular}




\begin{tabular}{|c|c|c|c|c|}
\hline Publication & Scope & Region & Positive influence & Negative influence \\
\hline Moreno et al., 2016 & $\begin{array}{l}\text { Self-harm on social } \\
\text { media }\end{array}$ & & & $\begin{array}{l}\text { The intention of self- } \\
\text { injury was found using } \\
\text { certain hashtags on } \\
\text { Instagram }\end{array}$ \\
\hline Paul \& Fleming, 2019 & $\begin{array}{l}\text { MindShift (m-health), } \\
\text { alternative treatment } \\
\text { for anxiety disorders }\end{array}$ & $\begin{array}{l}\text { America (United } \\
\text { States) }\end{array}$ & $\begin{array}{l}\text { Mobile health has reduced } \\
\text { somatic anxiety by } 18 \% \\
\text { and depression symptoms } \\
\text { by } 22 \% \text { to a manageable } \\
\text { level and improve } \\
\text { student's quality of life }\end{array}$ & \\
\hline $\begin{array}{l}\text { Tangmunkongvorakul } \\
\text { et al., } 2019\end{array}$ & $\begin{array}{l}\text { Smartphone use and } \\
\text { psychological well- } \\
\text { being }\end{array}$ & $\begin{array}{l}\text { Asia (Chiang } \\
\text { Mai, Thailand) }\end{array}$ & & $\begin{array}{l}\text { Females students had } \\
\text { psychological well-being } \\
\text { scores that were higher } \\
\text { than males }\end{array}$ \\
\hline Van Der Merwe, 2019 & $\begin{array}{l}\text { ICT use pattern and } \\
\text { well-being of open } \\
\text { distance learning } \\
\text { students }\end{array}$ & $\begin{array}{l}\text { Africa (South } \\
\text { Africa) }\end{array}$ & $\begin{array}{l}\text { Students have a low risk of } \\
\text { overuse symptoms and } \\
\text { sleep deprivation }\end{array}$ & \\
\hline Wahyuni et al., 2019 & $\begin{array}{l}\text { Gadgets and mental } \\
\text { health }\end{array}$ & Asia (Indonesia) & & $\begin{array}{l}\text { High-frequency use of } \\
\text { digital gadgets affects } \\
\text { mental-emotional health }\end{array}$ \\
\hline Wang et al., 2019 & $\begin{array}{l}\text { Impact of smartphone } \\
\text { dependence on sleep } \\
\text { and health }\end{array}$ & $\begin{array}{l}\text { Asia (Southern } \\
\text { Taiwan) }\end{array}$ & & $\begin{array}{l}95 \% \text { of students who } \\
\text { used screen devices } \\
\text { before sleep have a } \\
\text { higher chance of getting } \\
\text { anxiety symptoms }\end{array}$ \\
\hline Woods \& Scott, 2016 & $\begin{array}{l}\text { Social media usage } \\
\text { affected sleep quality, } \\
\text { self-esteem, anxiety } \\
\text { and depression. }\end{array}$ & $\begin{array}{l}\text { Europe } \\
\text { (Scotland, } \\
\text { United Kingdom) }\end{array}$ & & $\begin{array}{l}\text { Social media use at night } \\
\text { linked to loss of sleep, } \\
\text { anxiety and depression }\end{array}$ \\
\hline Zhao et al., 2017 & $\begin{array}{l}\text { Internet addiction and } \\
\text { depression }\end{array}$ & $\begin{array}{l}\text { Asia (Anhui } \\
\text { province, China) }\end{array}$ & & $\begin{array}{l}22 . \% \text { of internet-addicted } \\
\text { participants experienced } \\
\text { depression }\end{array}$ \\
\hline
\end{tabular}

\section{Methodology}

In order to review the influence of ICT on teenagers, articles from the past five years were collected for analysis. To avoid possible selection bias, criteria for this review were developed with the intent of locating all relevant articles.

\subsection{Data source and search strategies}

Several databases had been thoroughly searched, including ScienceDirect, Scopus, ResearchGate, Google Scholar. Databases were searched for peer-reviewed articles in the English language and limited by years, range from 2015 to 2020 and open access articles. Besides, the search terms were used to retrieve many relevant studies for the review even though some keywords have low precision that returned many irrelevant articles to the study. However, some articles are collected from references within a research article. The search was mainly focusing on the four components, skills, competencies, well-being and health in teenagers.

The total articles recorded were 75, after Inclusion and exclusion (refer to section 3.2) has been applied. The search methods and results are described in Table 5.
Table 5. Search method to find relevant topic for review

\begin{tabular}{|c|c|c|c|}
\hline Database & $\begin{array}{l}\text { Search } \\
\text { terms/keywords }\end{array}$ & $\begin{array}{l}\text { Number } \\
\text { of } \\
\text { results }\end{array}$ & $\begin{array}{l}\text { Relevant } \\
\text { topics } \\
\text { recorded }\end{array}$ \\
\hline \multirow{3}{*}{$\begin{array}{l}\text { ScienceDirect } \\
\text { Filtered by } \\
\text { (Research } \\
\text { articles, Year: } \\
2015 \text { - 2020, } \\
\text { Access type: } \\
\text { Open Access) }\end{array}$} & $\begin{array}{l}\text { ("digital device" } \\
\text { OR technolog?) } \\
\text { AND (skills OR } \\
\text { competent?) AND } \\
\text { (student? OR } \\
\text { teen? OR youth) }\end{array}$ & 113 & 15 \\
\hline & $\begin{array}{l}\text { "mhealth" AND } \\
\text { intervention? AND } \\
\text { "health" AND } \\
\text { (student? OR } \\
\text { "youth" OR teen?) }\end{array}$ & 52 & 3 \\
\hline & $\begin{array}{l}\text { "ICT" AND "well- } \\
\text { being" AND } \\
\text { ("youth" OR teen? }\end{array}$ & 71 & 2 \\
\hline
\end{tabular}




\begin{tabular}{|c|c|c|c|}
\hline \multirow[t]{4}{*}{ Database } & $\begin{array}{l}\text { Search } \\
\text { terms/keywords }\end{array}$ & $\begin{array}{l}\text { Number } \\
\text { of } \\
\text { results }\end{array}$ & $\begin{array}{l}\text { Relevant } \\
\text { topics } \\
\text { recorded }\end{array}$ \\
\hline & OR student?) & & \\
\hline & $\begin{array}{l}\text { "ICT" AND "well- } \\
\text { being" AND } \\
\text { "developing } \\
\text { country" AND } \\
\text { ("youth" OR } \\
\text { "students") }\end{array}$ & 17 & 0 \\
\hline & $\begin{array}{l}\text { "ICT" AND } \\
\text { ("health" OR } \\
\text { "well-being") AND } \\
\text { "rural areas" AND } \\
\text { ("youth" OR } \\
\text { "students") }\end{array}$ & 64 & 2 \\
\hline \multirow{2}{*}{$\begin{array}{l}\text { Scopus } \\
\text { Limit to } \\
\text { (“Open } \\
\text { Access", } \\
\text { Year: } 2015 \text { - } \\
2020, \\
\text { Research } \\
\text { article, } \\
\text { Language: } \\
\text { English) }\end{array}$} & $\begin{array}{l}\text { "ICT" AND "well- } \\
\text { being" AND } \\
\text { (“youth" OR teen* } \\
\text { OR student") }\end{array}$ & 191 & 6 \\
\hline & $\begin{array}{l}\text { "digital device" } \\
\text { AND "health" AND } \\
\text { ("youth" OR teen* } \\
\text { OR student*) }\end{array}$ & 157 & 5 \\
\hline \multirow{2}{*}{$\begin{array}{l}\text { ResearchGate } \\
\text { (Filtered to: } \\
\text { Publications, } \\
\text { Type: Article) }\end{array}$} & $\begin{array}{l}\text { ICT AND "rural } \\
\text { areas" AND } \\
\text { students }\end{array}$ & & 3 \\
\hline & $\begin{array}{l}\text { ICT AND health } \\
\text { AND youth }\end{array}$ & & 0 \\
\hline \multirow[t]{4}{*}{ Google Scholar } & $\begin{array}{l}\text { ICT AND } \\
\text { "learning" AND } \\
\text { "students" }\end{array}$ & & 7 \\
\hline & $\begin{array}{l}\text { technologies AND } \\
\text { "Health OR well- } \\
\text { being" AND } \\
\text { teenagers }\end{array}$ & & 4 \\
\hline & $\begin{array}{l}\text { Digital device } \\
\text { AND skills OR } \\
\text { competencies } \\
\text { AND teenagers }\end{array}$ & & 9 \\
\hline & $\begin{array}{l}\text { "social network" } \\
\text { AND "learning" } \\
\text { AND "students" }\end{array}$ & & 3 \\
\hline \multicolumn{3}{|c|}{$\begin{array}{l}\text { Total (Including references within a research } \\
\text { article) }\end{array}$} & 75 \\
\hline
\end{tabular}

\subsection{Inclusion and exclusion criteria}

The initial search in the databases yielded a high number of results. Therefore, search results are filtered to select only peer-reviewed articles. Other document type has been excluded so that only articles based on the original findings are on the eligible list. To be included in this review, each research study must meet the criteria as described in Table 6.
Thus, studies were excluded if they did not meet those criteria listed.

Table 6. Inclusion and exclusion description

\begin{tabular}{|l|l|l|}
\hline Criteria & Inclusion & Exclusion \\
\hline $\begin{array}{l}\text { Research } \\
\text { theme }\end{array}$ & $\begin{array}{l}\text { ICT, skills, } \\
\text { competencies, well- } \\
\text { being, health }\end{array}$ & $\begin{array}{l}\text { Articles that do not } \\
\text { cover these four } \\
\text { components }\end{array}$ \\
\hline $\begin{array}{l}\text { Article } \\
\text { publication } \\
\text { date }\end{array}$ & 2015 to 2020 & $\begin{array}{l}\text { Prior to 2015 and } \\
\text { after 2020 }\end{array}$ \\
\hline $\begin{array}{l}\text { Document } \\
\text { type }\end{array}$ & $\begin{array}{l}\text { Scholarly articles of } \\
\text { original research and } \\
\text { peer-reviewed }\end{array}$ & $\begin{array}{l}\text { Conference paper, } \\
\text { book, editorial or } \\
\text { dissertations }\end{array}$ \\
\hline Language & $\begin{array}{l}\text { Article written in } \\
\text { English }\end{array}$ & $\begin{array}{l}\text { Other languages } \\
\text { were not included }\end{array}$ \\
\hline Access type & $\begin{array}{l}\text { Only open access } \\
\text { article was chosen }\end{array}$ & $\begin{array}{l}\text { Other access type } \\
\text { was eliminated }\end{array}$ \\
\hline
\end{tabular}

\subsection{Data extraction and evidence synthesis}

Pertinent information from each of the identified studies was extracted, including authors, year of publication, research scope, region and study results (positive and negative influence). The trend of publication was also determined to find the frequency of research articles published based on the study aim in past years.

Each reviewed article was scrutinized to find how other researchers applied different research methods in their studies. In order to analyse the influences of ICT, selected articles are read thoroughly to identify research focus based on the four aspects of this study (skills, competencies, health and well-being).

\section{Findings}

This section summarizes and discusses the main findings of the review. Based on the articles collected, we made the following observations:

\subsection{Publication trends analysis}

Bar charts were generated to analyse the frequency of research conducted on the effects of ICT on skills, competencies, health and well-being of teenagers for a period of five years, 2015 to 2020. As depicted in (Fig. 1), the total number of studies for each component for the past few years but lack in significance as the result collected was only based on research articles. 


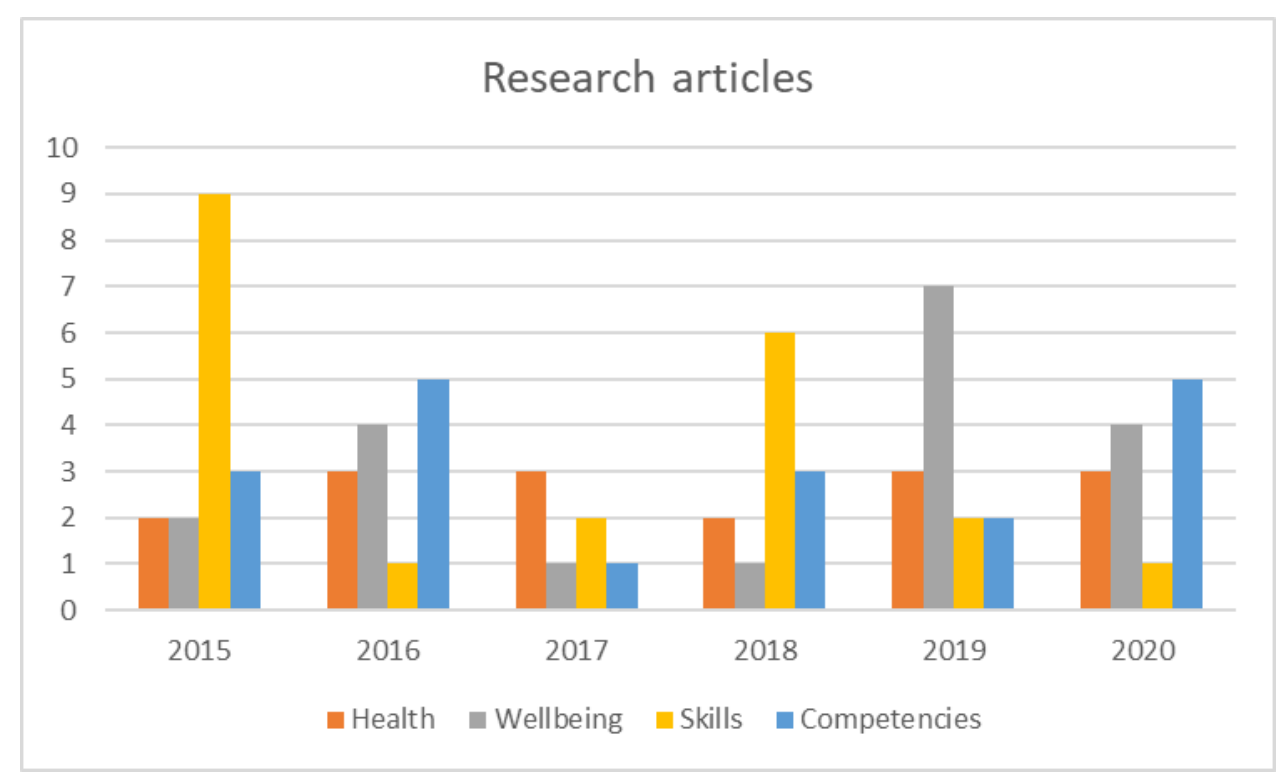

Figure 1. Number of Research Articles (2015-2020)

\subsection{Research methodology and settings}

The research methods used in the studies were classified into quantitative, qualitative and mixed methods. Table 7 below shows that more than half of the studies adopted the quantitative method $(\mathrm{n}=51)$, followed by mixed-method ( $\mathrm{n}$ $=16)$ and qualitative method $(\mathrm{n}=8)$. According to the literature in Section 2, the vast majority of research used high school as the research setting. In addition, based on the findings in Section 2, it is also worth mentioning that the predominant investigation was conducted in several parts of Asia $(\mathrm{n}=19)$ and Europe $(\mathrm{n}=15)$. While, America $(\mathrm{n}=13)$, Africa $(n=4)$ and Oceania $(n=2)$ respectively.

Table 7. Research components and methodology of previous studies

\begin{tabular}{|l|l|l|l|}
\hline Component & $\begin{array}{l}\text { Qualitative } \\
\text { method }\end{array}$ & $\begin{array}{l}\text { Quantitative } \\
\text { method }\end{array}$ & $\begin{array}{l}\text { Mixed } \\
\text { methods }\end{array}$ \\
\hline Skills & 2 & 17 & 3 \\
\hline Competencies & 1 & 14 & 1 \\
\hline Health & 2 & 8 & 7 \\
\hline Well-being & 3 & 12 & 5 \\
\hline Total & 8 & 51 & 16 \\
\hline
\end{tabular}

\subsection{Study content focus and types of ICT}

Each of the articles reviewed yielded findings relevant to the association between ICT and its influence on teenagers' skills, competencies, health and well-being.

\section{Skills}

Previous studies that focused on teenagers' skills found both positive and negative influences from ICT. The studies concluded several prominent influences on their skills and can be divided into different types of ICT that include the internet, mobile devices and computer.

Five studies found that teenagers who use mobile phones and computers to access the internet are more likely to have digital literacy improved that contributed to their awareness and perception of the risk related to the publication of data online $[25-27,29,30]$. Moreover, three studies examined the same technologies (internet, mobile phones, computer) influence their digital skills that facilitate learning experience $[28,31,32]$.

In contrast, two studies identified that mobile devices are the main moderator for teenagers to use their skills to conduct academic cheating and that males are more likely to have such behaviour [34][35].

\section{Competencies}

Three studies agreed that computer and mobile devices have a significant influence on teenagers' competencies. Teenagers who use such devices are more digital literate that enables them to be more competent in terms of academic settings $[37,38,45]$.

However, studies also revealed that the influence of addictive smartphone uses is the main contributor to low academic competence [41-43] because the extended use of 
smartphones caused teenagers to be unable to concentrate in studies [40].

\section{Health}

A number of studies discovered that mobile phones are an important technological tool to improve teenager health, especially, those who reside in rural areas. Such mobile phones used internet connection and application to effectively monitor teenagers' health [48-50].

On the other hand, numerous studies found that the use of computers excessively and that teenagers practicing sedentary lifestyle caused the increase in body weight $[51,52,54-56]$ that connected closely to poor physical health and dietary habits $[51,54,55]$. Besides, the influence of mobile devices on teenagers with the increase of musculoskeletal and vision symptoms [57,58] has significantly increased. This includes pain and stiffness on the shoulder, neck and lower back area as well as vision loss [78]. In addition, addiction to mobile devices and social media also affects their sleeping hours [51-53].

\section{Well-being}

A recent study was conducted to investigate the use of social media in contributing to teenagers' well-being. The authors asserted that teenager who use social media to communicate with peers tends to felt better [60]. Furthermore, mobile devices are vital to help teenagers who are suffering from psychological disorders in monitoring their symptoms and to improve their overall well-being [63].

Despite that, the majority of the studies discovered the high-frequency use of mobile phones and the internet are closely associated with depression and anxiety $[67,69,70,72-74,76]$. The influence of mobile device usage can be a severe problem for teenagers which studies have concluded that overuse may cause suicidal and self-harming ideation $[71,72,79]$.

\section{Discussion}

This review sought to assess the studies concerning the influence of ICT on teenagers. Further analysis of existing studies revealed a significant under-representation of research studying the effects of interaction between teenagers and ICT in terms of skills, competencies, wellbeing and health. This under-representation may be limiting the evidence to suggest an understanding of the effects of ICT on teenagers. Thus, addressing the gaps will be crucial to improve the understanding and ideas of the research areas. The following sections analyse the most studied research areas, least studied research areas and most used research methodologies from all the papers being reviewed.

\subsection{Most studied research areas}

Research on both negative implications of ICT on teenagers' well-being and health has experienced significant growth in the last years. Besides, it is also true of these areas' intersection, with increasing numbers of teenagers' well-being and health-related problem are being reported. The most prevalent of these problems reported is the excessive use of technologies (e.g., internet, computers, smartphones, mobile devices) associated with mental health issues and poor physical fitness. Several studies indicated that teenagers that are categorized into the same internet addiction (IA) cohort were linked to severe depressive symptoms $[64,73,74,76]$. One of the reasons is because the majority of teenagers have exceeded the ideal screen time limit when using digital devices. According to [64], teenagers' recommended screen time is a maximum of two hours per day. Besides, the extensive use of digital devices also constituted to poor physical health such as musculoskeletal pain, overweight or even unbalance diet [51,54,56-58].

\subsection{Least studied research areas}

The existing research has limited evidence on the negative implications of ICTs on teenagers' skills and competencies. As such, several studies discussed that teenagers had misused their digital skills to perform unethical conduct plagiarism, cyberbullying, and cybercrime $[33,35]$. The results further indicated that excessive use of digital devices is more likely associated with poor academic competencies [41-43] and due to lack of concentration and facilities in rural areas to assist their learning $[40,44]$.

Besides, there is a paucity of evidence to determine the positive effects of ICT on teenagers' health and well-being. Only several studies discussed how teenagers are exploiting technologies to improve their health and well-being. The studies covered teenagers from different countries (Bangladesh, Germany, Republic of Ireland) and aimed to introduce the integration of mobile health and internetassisted application to teenagers living in both developed and developing countries. Internet assisted mobile health (mHealth) application such as CopeSmart was created to help teenage patients to consult physician or therapist on a health-related matter over the internet $[49,50]$ and it is particularly useful for them that are living in geographically isolated and disadvantaged areas. The main differences are clear enough to distinguish technologies' exposure to improve health among teenagers from urban and rural areas. The study on teenagers from rural areas in Sweden has restricted access to healthcare technologies and services [47].

\subsection{Most used research methodologies}

The methodology used from the reviewed articles is mostly involved in quantitative research. Most researchers are practicing this method when collecting and analysing data. 
Some studies also aim to focus on validating theories and hypotheses $[67,69,74]$. This method requires a large number of respondents to perform statistical analysis and to draw conclusions based on the derived hypothesis. The data gathered is based on numbers and the results are often reported in graphs or tables. However, several limitations of quantitative research should be considered, in which data obtained are more narrowed focus, structural bias and lack of context. Besides, some studies adopt a mixed-methods approach $[3,47,62]$, where both quantitative and qualitative methods are being used. Hence, both approaches are essential for gaining different kinds of knowledge. Moreover, several major studies are performing selfreported measures that may be subjected to bias outcomes and subsequently decrease the results' accuracy.

Overall, the findings in this review show the current state of ICT impacts on teenagers despite the existence of limitations and to provide a comprehensive knowledge of this research area and at the same time present researchbased evidence that may beneficially contribute to future studies.

\section{Conclusion and future works}

The findings of this study showed a diverse influence of ICT usage in skills, competencies, well-being and health of teenagers. Several potential apparent negative effects can be highlighted. The excessive use of the technologies has projected the impact to the extent where the abuse of digital skills among teenagers includes plagiarizing, cyberbullying and cybercrime. These misconducts have created a considerable influence on the teenager's overall development.

It has also been identified that the increase in usage of gadgets leads to poor academic performance and competencies in teenagers. The main reason is the loss of interest or concentration on studies when teenagers are prone to gadgets addiction. Therefore, the likelihood of gadget addiction is correlated to distraction and failure to achieve academic success.

Social media usage by teenagers in an extensive manner has resulted in the risk of getting depression consequently, increases academic stress and contributes to negative wellbeing. The situation where teenagers spend less time in physical activities and more screen time particularly social media has caused them to be socially isolated. This has somewhat constituted the ideation of self-harm or suicide. Also, prolonged use of devices may cause delayed sleep schedules, potentially increasing the chances of depression, anxiety and social problems.

Health complications are noticeable where the use of electronic devices for long hours is associated with the consumption of sugary beverages and the promotion of a sedentary lifestyle. This has resulted in teenagers being less active and having poor dietary habits. The sedentary behaviour not only affects the increase of body weight but also leads to musculoskeletal symptoms such as back pain, fatigue and sleep disturbance. Therefore, the results of the current study suggest that the use of ICTs may have both positive and negative implications for teenagers.

Based on the studies reviewed, it is apparent that some extensive and comprehensive research should be conducted to gather information on how ICTs have influenced teenagers in different regions of the world. The regional study may help the researchers to identify positive and negative influences of ICT adoption among the population; nevertheless, it can provide insights on how to mitigate the risks of the increasing negative impacts and tap on to the benefits of the readily available positive impacts, effectively. Besides, more research should be presented on how teenagers from different geographical locations, namely urban and rural areas, are engaging with ICTs to extend their academic performance abilities.

While it is helpful to see research involving technologies on improving teenagers' overall healthcare, but the current knowledge on its positive influence is still narrow; therefore, further studies on this gap should be carried out. It is recommended that studies should focus on the implementation and adoption of mobile health applications that aim to increase the outreach on health services among teenagers, notably from rural areas.

\section{References}

[1] M. Arrosagaray, M. González-Peiteado, M. Pino-Juste, B. Rodríguez-López, A comparative study of Spanish adult students' attitudes to ICT in classroom, blended and distance language learning modes, Comput. Educ. 134 (2019) 31-40. https://doi.org/10.1016/j.compedu.2019.01.016.

[2] M.C. Vega-Hernández, M.C. Patino-Alonso, M.P. GalindoVillardón, Multivariate characterization of university students using the ICT for learning, Comput. Educ. 121 (2018) 124130. https://doi.org/10.1016/j.compedu.2018.03.004.

[3] O.D. Apuke, T.O. Iyendo, University students' usage of the internet resources for research and learning: forms of access and perceptions of utility, Heliyon. 4 (2018) e01052. https://doi.org/10.1016/j.heliyon.2018.e01052.

[4] C. Barhoumi, The Effectiveness of WhatsApp Mobile Learning Activities Guided by Activty Theory on Students' Knowldege Management, Contemp. Educ. Technol. 6 (2020). https://doi.org/10.30935/cedtech/6151.

[5] W. Wargadinata, I. Maimunah, E. Dewi, Z. Rofiq, Student's Responses on Learning in the Early COVID-19 Pandemic, Tadris J. Kegur. Dan Ilmu Tarb. 5 (2020) 141-153. https://doi.org/10.24042/tadris.v5i1.6153.

[6] T. Koç, A.H. Turan, A. Okursoy, Acceptance and usage of a mobile information system in higher education: An empirical study with structural equation modeling, Int. J. Manag. Educ. 14 (2016) 286-300. https://doi.org/10.1016/j.ijme.2016.06.001.

[7] L. Shuib, S. Shamshirband, M.H. Ismail, A review of mobile pervasive learning: Applications and issues, Comput. Human Behav. 46 (2015) 239-244. https://doi.org/10.1016/j.chb.2015.01.002.

[8] H. Hamidi, A. Chavoshi, Analysis of the essential factors for the adoption of mobile learning in higher education: A case study of students of the University of Technology, Telemat. 
Informatics. $\quad 35 \quad$ (2018) $\quad 1053-1070$. https://doi.org/10.1016/j.tele.2017.09.016.

[9] A. Al-Hunaiyyan, R.A. Alhajri, S. Al-Sharhan, Perceptions and challenges of mobile learning in Kuwait, J. King Saud Univ. - Comput. Inf. Sci. 30 (2018) 279-289. https://doi.org/10.1016/j.jksuci.2016.12.001.

[10] E.M. Mojaye, Mobile Phone Usage Among Nigerian University Students and Its Impact on Teaching and Learning, Glob. J. Arts Humanit. Soc. Sci. 3 (2015) 29-38. http://www.eajournals.org/wp-content/uploads/MobilePhone-Usage-among-Nigerian-University-Students-and-ItsImpact-On-Teaching-And-Learning.pdf.

[11] H. Jafarkarimi, A.T.H. Sim, R. Saadatdoost, J.M. Hee, Individual characteristics and hacking, piracy, online gambling and pornography use among students: A study in Malaysia, Int. J. Cyber Behav. Psychol. Learn. 5 (2015) 3043. https://doi.org/10.4018/IJCBPL.2015040103.

[12] M.I.M. Eid, I.M. Al-Jabri, Social networking, knowledge sharing, and student learning: The case of university students, $\begin{array}{llll}\text { Comput. } & \text { Educ. } & 99 & \text { (2016) }\end{array}$ https://doi.org/10.1016/j.compedu.2016.04.007.

[13] J. Lim, J.C. Richardson, Exploring the effects of students' social networking experience on social presence and perceptions of using SNSs for educational purposes, Internet High. $\quad$ Educ. $29 \quad$ (2016) 31-39. https://doi.org/10.1016/j.iheduc.2015.12.001.

[14] S. Hamid, J. Waycott, S. Kurnia, S. Chang, Understanding students' perceptions of the benefits of online social networking use for teaching and learning, Internet High. $\begin{array}{llll}\text { Educ. } & 26 & \text { (2015) }\end{array}$ https://doi.org/10.1016/j.iheduc.2015.02.004.

[15] M.W. Tsappis, 29.3 When Online Gaming Stops Being Fun: Helping College Students Cope With Problematic Internet Use, J. Am. Acad. Child Adolesc. Psychiatry. 58 (2019) S42S43. https://doi.org/10.1016/j.jaac.2019.07.179.

[16] C.C. Hsu, T.I. Wang, Applying game mechanics and studentgenerated questions to an online puzzle-based game learning system to promote algorithmic thinking skills, Comput. Educ. 121 (2018) https://doi.org/10.1016/j.compedu.2018.02.002.

[17] D.O. Dumrique, J.G. Castillo, Online Gaming: Impact on the Academic Performance and Social Behavior of the Students in Polytechnic University of the Philippines Laboratory High School, KnE Soc. Sci. 3 (2018) 1205. https://doi.org/10.18502/kss.v3i6.2447.

[18] A. Drummond, J.D. Sauer, Timesplitters: Playing video games before (but not after) school on weekdays is associated with poorer adolescent academic performance. A test of competing theoretical accounts, Comput. Educ. 144 (2020) 103704. https://doi.org/10.1016/j.compedu.2019.103704.

[19] R. Scherer, O.E. Hatlevik, "Sore eyes and distracted" or "excited and confident"? - The role of perceived negative consequences of using ICT for perceived usefulness and selfefficacy, Comput. Educ. $115 \quad$ (2017) 188-200. https://doi.org/10.1016/j.compedu.2017.08.003.

[20] S.H. Toh, P. Coenen, E.K. Howie, A.J. Smith, S. Mukherjee, D.A. Mackey, L.M. Straker, A prospective longitudinal study of mobile touch screen device use and musculoskeletal symptoms and visual health in adolescents, Appl. Ergon. 85 (2020) 103028. https://doi.org/10.1016/j.apergo.2019.103028.

[21] E.C. Kranzler, A. Bleakley, Youth Social Media Use and Health Outcomes: \#diggingdeeper, J. Adolesc. Heal. 64 (2019) https://doi.org/10.1016/j.jadohealth.2018.11.002.

[22] V. Ilakkuvan, A. Johnson, A.C. Villanti, W.D. Evans, M. Turner, Patterns of Social Media Use and Their Relationship to Health Risks Among Young Adults, J. Adolesc. Heal. 64 (2019) https://doi.org/10.1016/j.jadohealth.2018.06.025.

[23] F. Siddiq, O.E. Hatlevik, R.V. Olsen, I. Throndsen, R. Scherer, Taking a future perspective by learning from the past - A systematic review of assessment instruments that aim to measure primary and secondary school students' ICT literacy, Educ. Res. Rev. 19 (2016) 58-84. https://doi.org/10.1016/j.edurev.2016.05.002.

[24] Y.J. Wu, C. Outley, D. Matarrita-Cascante, T.P. Murphrey, A Systematic Review of Recent Research on Adolescent Social Connectedness and Mental Health with Internet Technology Use, Adolesc. Res. Rev. 1 (2016) 153-162. https://doi.org/10.1007/s40894-015-0013-9.

[25] A. Lareki, J.I. Martínez de Morentin, J. Altuna, N. Amenabar, Teenagers' perception of risk behaviors regarding digital technologies, Comput. Human Behav. 68 (2017) 395402. https://doi.org/10.1016/j.chb.2016.12.004.

[26] S. Park, E.M. Kim, E.Y. Na, Online Activities, Digital Media Literacy, and Networked Individualism of Korean Youth, $\begin{array}{lllll}\text { Youth } & \text { Soc. } & 47 & \text { (2015) } & \text { 829-849. }\end{array}$ https://doi.org/10.1177/0044118X14561008

[27] I. Rodríguez-de-Dios, J.M.F. van Oosten, J.J. Igartua, A study of the relationship between parental mediation and adolescents' digital skills, online risks and online opportunities, Comput. Human Behav. 82 (2018) 186-198. https://doi.org/10.1016/j.chb.2018.01.012.

[28] A. Viloria, O.B. Pineda Lezama, N. Mercado-Caruzo, Factors that describe the use of digital devices in Latin American universities, Procedia Comput. Sci. 175 (2020) 127-134. https://doi.org/10.1016/j.procs.2020.07.021.

[29] J. Picatoste, L. Pérez-Ortiz, S.M. Ruesga-Benito, A new educational pattern in response to new technologies and sustainable development. Enlightening ICT skills for youth employability in the European Union, Telemat. Informatics. 35 (2018) 1031-1038. https://doi.org/10.1016/j.tele.2017.09.014.

[30] T. Cabello-Hutt, P. Cabello, M. Claro, Online opportunities and risks for children and adolescents: The role of digital skills, age, gender and parental mediation in Brazil, New $\begin{array}{llll}\text { Media } & \text { Soc. } 20 & \text { (2017) 2411-2431. }\end{array}$ https://doi.org/10.1177/1461444817724168.

[31] C. McGuinness, C. Fulton, Digital literacy in higher education: A case study of student engagement with etutorials using blended learning, J. Inf. Technol. Educ. Innov. Pract. 18 (2019) 1-28. https://doi.org/10.28945/4190.

[32] M.E. Gioiosa, K. Kinkela, Classroom exercises with technology and communication skills: students' perceptions, $\begin{array}{lllll}\text { J. Int. Educ. } & \text { Bus. } 12 \quad \text { (2019) }\end{array}$ https://doi.org/10.1108/JIEB-02-2018-0005.

[33] D. West, An investigation into the prevalence of cyberbullying among students aged $16-19$ in postcompulsory education, Res. Post-Compulsory Educ. 20 (2015) https://doi.org/10.1080/13596748.2015.993879.

[34] N.G. Ugur, T. Koc, Time for Digital Detox: Misuse of Mobile Technology and Phubbing, Procedia - Soc. Behav. Sci. $\quad 195 \quad$ (2015) 1022-1031. https://doi.org/10.1016/j.sbspro.2015.06.491

[35] J.S. Negre, R. Comas-Forgas, M.F. Oliver-Trobat, Academic plagiarism among secondary and high school students: Differences in gender and procrastination, Comunicar. 22 (2015) 103-111. https://doi.org/10.3916/C44-2015-11.

[36] N. Asfar, Z. Zainuddin, Secondary Students' Perceptions of Information, Communication and Technology (ICT) Use In Promoting Self-directed Learning In Malaysia, 3 (2015). 
https://www.researchgate.net/publication/316986236 SECO NDARY STUDENTS' PERCEPTIONS OF INFORMATI ON_COMMUNICATION_AND_TECHNOLOTOGY_ICT_US E IN PROMOTING SELFDIRECTED LEARNING IN MALAYSIA.

[37] L. Pagani, $\overline{\text { G. }}$ Argentin, $\bar{M}$. Gui, L. Stanca, The impact of digital skills on educational outcomes: evidence from performance tests, Educ. Stud. 42 (2016) 137-162. https://doi.org/10.1080/03055698.2016.1148588.

[38] A. Shonola, M. Joy, S.S. Oyelere, J. Suhonen, The Impact of Mobile Devices for Learning in Higher Education Institutions: Nigerian Universities Case Study, Int. J. Mod.

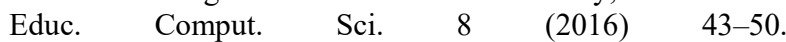
https://doi.org/10.5815/ijmecs.2016.08.06.

[39] B. Ferdousi, J. Bari, Infusing Mobile Technology into Undergraduate Courses for Effective Learning, Procedia Soc. Behav. Sci. 176 (2015) 307-311. https://doi.org/10.1016/j.sbspro.2015.01.476.

[40] S. Venkatapathy, R. Bhargavan, Impact of Smartphone Usage on the Academic Performance among Medical Students, J. Evol. Med. Dent. Sci. 9 (2020) 105-110. https://doi.org/10.14260/jemds/2020/23.

[41] A. Lepp, J.E. Barkley, A.C. Karpinski, The relationship between cell phone use and academic performance in a sample of U.S. college students, SAGE Open. 5 (2015). https://doi.org/10.1177/2158244015573169.

[42] S.E. Domoff, R.P. Foley, R. Ferkel, Addictive phone use and academic performance in adolescents, Hum. Behav. Emerg. Technol. 2 (2020) 33-38. https://doi.org/10.1002/hbe2.171.

[43] N. Othman, M. Khairuz, T.S.S. Jamaludin, The Impact of Electronic Gadget Uses with Academic Performance among Secondary School Students, Pr. Clin Invest. 2 (2020) 56-60. https://www.researchgate.net/publication/338791252_The_Im pact_of_Electronic_Gadget_Uses_with_Academic_Performa nce_among_Secondary_School_Students.

[44] C. Buabeng-Andoh, Y. Issifu, Implementation of ICT in Learning: A Study of Students in Ghanaian Secondary Schools, Procedia - Soc. Behav. Sci. 191 (2015) 1282-1287. https://doi.org/10.1016/j.sbspro.2015.04.555.

[45] R. Thinakaran, R. Ali, W. Nor Al-Ashekin Wan Husin, A Case Study of Undergraduate Students Computer SelfEfficacy from Rural Areas, Int. J. Eng. Technol. 7 (2018) 270. https://doi.org/10.14419/ijet.v7i3.20.19164.

[46] N. 'Atikah Ahmad, A.F.M. Ayub, M.N. Khambari, Gender Digital Divide: Digital Skills among Malaysian Secondary School, Int. J. Acad. Res. Progress. Educ. Dev. 8 (2019). https://doi.org/10.6007/ijarped/v8-i4/6692.

[47] I. Goicolea, D. Carson, M. San Sebastian, M. Christianson, M. Wiklund, A.K. Hurtig, Health care access for rural youth on equal terms? A mixed methods study protocol in northern Sweden, Int. J. Equity Health. 17 (2018) 1-9. https://doi.org/10.1186/s12939-018-0718-z.

[48] M.R. Hoque, An empirical study of mHealth adoption in a developing country: The moderating effect of gender concern, BMC Med. Inform. Decis. Mak. 16 (2016) 1-10. https://doi.org/10.1186/s12911-016-0289-0.

[49] R. Kenny, B. Dooley, A. Fitzgerald, Feasibility of "CopeSmart": A Telemental Health App for Adolescents, JMIR Ment. Heal. 2 (2015) e22. https://doi.org/10.2196/mental.4370.

[50] M. Harrer, S.H. Adam, R.J. Fleischmann, H. Baumeister, R. Auerbach, R. Bruffaerts, P. Cuijpers, R.C. Kessler, M. Berking, D. Lehr, D.D. Ebert, Effectiveness of an internetand app-based intervention for college students with elevated stress: Randomized controlled trial, J. Med. Internet Res. 20 (2018) 1-16. https://doi.org/10.2196/jmir.9293.
[51] E.L. Kenney, S.L. Gortmaker, United States Adolescents' Television, Computer, Videogame, Smartphone, and Tablet Use: Associations with Sugary Drinks, Sleep, Physical Activity, and Obesity, J. Pediatr. 182 (2017) 144-149. https://doi.org/10.1016/j.jpeds.2016.11.015.

[52] Q. Huang, Y. Li, S. Huang, J. Qi, T. Shao, X. Chen, Z. Liao, S. Lin, X. Zhang, Y. Cai, H. Chen, Smartphone Use and Sleep Quality in Chinese College Students: A Preliminary $\begin{array}{lllll}\text { Study, Front. Psychiatry. } 11 & \text { (2020) 1-7. }\end{array}$ https://doi.org/10.3389/fpsyt.2020.00352.

[53] J.C. Levenson, A. Shensa, J.E. Sidani, J.B. Colditz, B.A. Primack, The association between social media use and sleep disturbance among young adults, Prev. Med. (Baltim). 85 (2016) 36-41. https://doi.org/10.1016/j.ypmed.2016.01.001.

[54] T. Puolitaival, M. Sieppi, R. Pyky, H. Enwald, R. Korpelainen, M. Nurkkala, Health behaviours associated with video gaming in adolescent men: A cross-sectional population-based MOPO study, BMC Public Health. 20 (2020) 1-8. https://doi.org/10.1186/s12889-020-08522-x.

[55] K.M. Bradbury, O. Turel, K.M. Morrison, Electronic device use and beverage related sugar and caffeine intake in US adolescents, PLoS One. 14 (2019) 1-18. https://doi.org/10.1371/journal.pone.0223912.

[56] Y. Cai, X. Zhu, X. Wu, Overweight, obesity, and screen-time viewing among Chinese school-aged children: National prevalence estimates from the 2016 Physical Activity and Fitness in China-The Youth Study, J. Sport Heal. Sci. 6 (2017) 404-409. https://doi.org/10.1016/j.jshs.2017.09.002.

[57] L. Straker, C. Harris, J. Joosten, E.K. Howie, Mobile technology dominates school children's IT use in an advantaged school community and is associated with musculoskeletal and visual symptoms, Ergonomics. 61 (2018) https://doi.org/10.1080/00140139.2017.1401671.

[58] C. Harris, L. Straker, C. Pollock, A. Smith, Children, computer exposure and musculoskeletal outcomes: the development of pathway models for school and home computer-related musculoskeletal outcomes, Ergonomics. 58 (2015) https://doi.org/10.1080/00140139.2015.1035762.

[59] E.H.C. Woo, P. White, C.W.K. Lai, Musculoskeletal impact of the use of various types of electronic devices on university students in Hong Kong: An evaluation by means of selfreported questionnaire, Man. Ther. 26 (2016) 47-53. https://doi.org/10.1016/j.math.2016.07.004.

[60] I. Beyens, J.L. Pouwels, I.I. van Driel, L. Keijsers, P.M. Valkenburg, The effect of social media on well-being differs from adolescent to adolescent, Sci. Rep. 10 (2020) 1-11. https://doi.org/10.1038/s41598-020-67727-7.

[61] A. Meier, L. Reinecke, C.E. Meltzer, Facebocrastination? Predictors of using Facebook for procrastination and its effects on students' well-being, Comput. Human Behav. 64 (2016) 65-76. https://doi.org/10.1016/j.chb.2016.06.011.

[62] F. Mishna, C. Regehr, A. Lacombe-Duncan, J. Daciuk, G. Fearing, M. Van Wert, Social media, cyber-aggression and student mental health on a university campus, J. Ment. Heal. 27 (2018) 222-229. https://doi.org/10.1080/09638237.2018.1437607.

[63] A.M. Paul, C.J.E. Fleming, Anxiety Management on Campus: An Evaluation of a Mobile Health Intervention, J. Technol. Behav. Sci. 4 (2019) 58-61. https://doi.org/10.1007/s41347-018-0074-2.

[64] J. Liu, C. Liu, T. Wu, B.P. Liu, C.X. Jia, X. Liu, Prolonged mobile phone use is associated with depressive symptoms in Chinese adolescents, J. Affect. Disord. 259 (2019) 128-134. https://doi.org/10.1016/j.jad.2019.08.017. 
[65] M.A. Moreno, A. Ton, E. Selkie, Y. Evans, Secret Society 123: Understanding the Language of Self-Harm on Instagram, J. Adolesc. Heal. $58 \quad$ (2016) 78-84. https://doi.org/10.1016/j.jadohealth.2015.09.015.

[66] M. Liu, Q. Ming, J. Yi, X. Wang, S. Yao, Screen time on school days and risks for psychiatric symptoms and self-harm in mainland Chinese adolescents, Front. Psychol. 7 (2016) 111. https://doi.org/10.3389/fpsyg.2016.00574.

[67] A.S. Wahyuni, F.B. Siahaan, M. Arfa, I. Alona, N. Nerdy, The relationship between the duration of playing gadget and mental emotional state of elementary school students, Open Access Maced. J. Med. Sci. 7 (2019) 148-151. https://doi.org/10.3889/oamjms.2019.037.

[68] R. Chen, J. Liu, X. Cao, S. Duan, S. Wen, S. Zhang, J. Xu, L. Lin, Z. Xue, J. Lu, The relationship between mobile phone use and suicide-related behaviors among adolescents: The mediating role of depression and interpersonal problems, J. Affect. $\quad$ Disord. $269 \quad$ (2020) 101-107. https://doi.org/10.1016/j.jad.2020.01.128.

[69] E. McDool, P. Powell, J. Roberts, K. Taylor, The internet and children's psychological wellbeing, J. Health Econ. 69 (2020). https://doi.org/10.1016/j.jhealeco.2019.102274.

[70] H.C. Woods, H. Scott, \#Sleepyteens: Social media use in adolescence is associated with poor sleep quality, anxiety, depression and low self-esteem, J. Adolesc. 51 (2016) 41-49. https://doi.org/10.1016/j.adolescence.2016.05.008.

[71] M.J. George, M.R. Jensen, M.A. Russell, A. Gassman-Pines, W.E. Copeland, R.H. Hoyle, C.L. Odgers, Young Adolescents' Digital Technology Use, Perceived Impairments, and Well-Being in a Representative Sample, J. Pediatr. $219 \quad$ (2020) 180-187. https://doi.org/10.1016/j.jpeds.2019.12.002.

[72] P.Y. Wang, K.L. Chen, S.Y. Yang, P.H. Lin, Relationship of sleep quality, smartphone dependence, and health-related behaviors in female junior college students, PLoS One. 14 (2019) 1-12. https://doi.org/10.1371/journal.pone.0214769.

[73] K. Demirci, M. Akgönül, A. Akpinar, Relationship of smartphone use severity with sleep quality, depression, and anxiety in university students, J. Behav. Addict. 4 (2015) 8592. https://doi.org/10.1556/2006.4.2015.010.

[74] F. Zhao, Z.H. Zhang, L. Bi, X.S. Wu, W.J. Wang, Y.F. Li, Y.H. Sun, The association between life events and internet addiction among Chinese vocational school students: The mediating role of depression, Comput. Human Behav. 70 (2017) 30-38. https://doi.org/10.1016/j.chb.2016.12.057.

[75] A. Tangmunkongvorakul, P.M. Musumari, K. Thongpibul, K. Srithanaviboonchai, T. Techasrivichien, S. Pilar Suguimoto, M. Ono-Kihara, M. Kihara, Association of excessive smartphone use with psychological well-being among university students in Chiang Mai, Thailand, PLoS One. 14 (2019) 1-13. https://doi.org/10.1371/journal.pone.0210294.

[76] L.O. Coleman, T.M. Hale, S.R. Cotten, P. Gibson, The Impact of Information and Communication Technology (ICT) Usage on Psychological Well-Being Among Urban Youth, (2015) iii. https://doi.org/10.1108/s1537466120150000019024.

[77] D. Van Der Merwe, Exploring the relationship between ICT use, mental health symptoms and well-being of the historically disadvantaged open distance learning student: A case study, Turkish Online J. Distance Educ. 20 (2019) 3552. https://doi.org/10.17718/tojde.522373.

[78] E.H.C. Woo, P. White, C.W.K. Lai, Impact of information and communication technology on child health, J. Paediatr. Child Health. 52 (2016) 590-594. https://doi.org/10.1111/jpc.13181.

[79] M. Liu, Q. Ming, J. Yi, X. Wang, S. Yao, Screen Time on School Days and Risks for Psychiatric Symptoms and SelfHarm in Mainland Chinese Adolescents, Front. Psychol. 7 (2016) 574. https://doi.org/10.3389/fpsyg.2016.00574. 